\title{
HYDROCARBON POTENTIALITY OF FACHA RESERVOIR IN ASWAD OIL FIELD, SIRT BASIN, LIBYA
}

\author{
A. A. Kushlaf ${ }^{1}$ and A. E. El Mezweghy ${ }^{2}$ \\ ${ }^{1,2}$ Engineering Geology Department, Faculty of Oil and Gas, Al Zawia University, Libya. \\ 1‥Kushlaf@zu.edu.ly
}

\begin{abstract}
This paper is to study the structural framework, stratigraphy, and the petro-physical characteristics of Facha reservoir of Gir Formation in Aswad oil field, which is located in Block NC74B at the Zella Trough, south-west of Sirt basin, Libya. The data used have been got from well-logging records of nine exploratory wells distributed in Aswad oil field. These data have been analyzed and interpreted through using analytical cross-plots in order to calculate the petro-physical parameters. The results revealed that the lithological facies consists mainly of dolomite. Moreover, they revealed that the lateral distribution of the petro-physical parameters of Facha reservoir indicates that average porosity is 10-23\%, average water saturation is $52-93 \%$, and net pay is of $62.44 \mathrm{ft}$. This shows that Facha member is a good reservoir rock. The variations in values between wells have been affected by the trend of faults; this indicates that the area is structurally controlled.
\end{abstract}

Keywords: Aswad field, Facha Member, well logging, petro-physical parameters.

\section{Introduction}

Aswad field was discovered by Elwerath Oil Company in 1961 when the first discovery well (B1-74) was drilled. This field lies a few kilometers south of Zella Field in Sirt Basin. It is located between latitude $28^{\circ} 29^{\prime} 59.2^{\prime \prime}$ and $29^{\circ} 00^{\prime} 00^{\prime \prime}$ North and between longitudes $17^{\circ} 19^{\prime}$ and $17^{\circ} 24^{\prime}$ Figure (1). The reservoir rock of the field area is Lower Eocene and consists of dolomite at concession 74 (Zueitina Oil Company, 2010).

The main purpose of this study is to understand the structural framework and the general stratigraphy of this field; it also aims to investigate the petro-physical characteristics of the Facha Reservoir namely reservoir porosity, fluid type and content, and net pay thickness.

The available well logging data, which include resistivity, gamma ray, density, and neutron logs have been used for correlation and for the construction of different maps and crosssections. The logs have been analyzed every $2 \mathrm{ft}$., and the relationships between the structural main trends with petro-physical characteristics have been discussed.

Though this study focuses mainly on the quick look analysis of log curves and on plotting cross plots between the petro-physical parameters, it can be considered as an extension to a previous study conducted by Selim et al. in 2015 in which they analyzed the petro-physical characteristics of Hawaz formation in $\mathrm{H}$ oil field. 


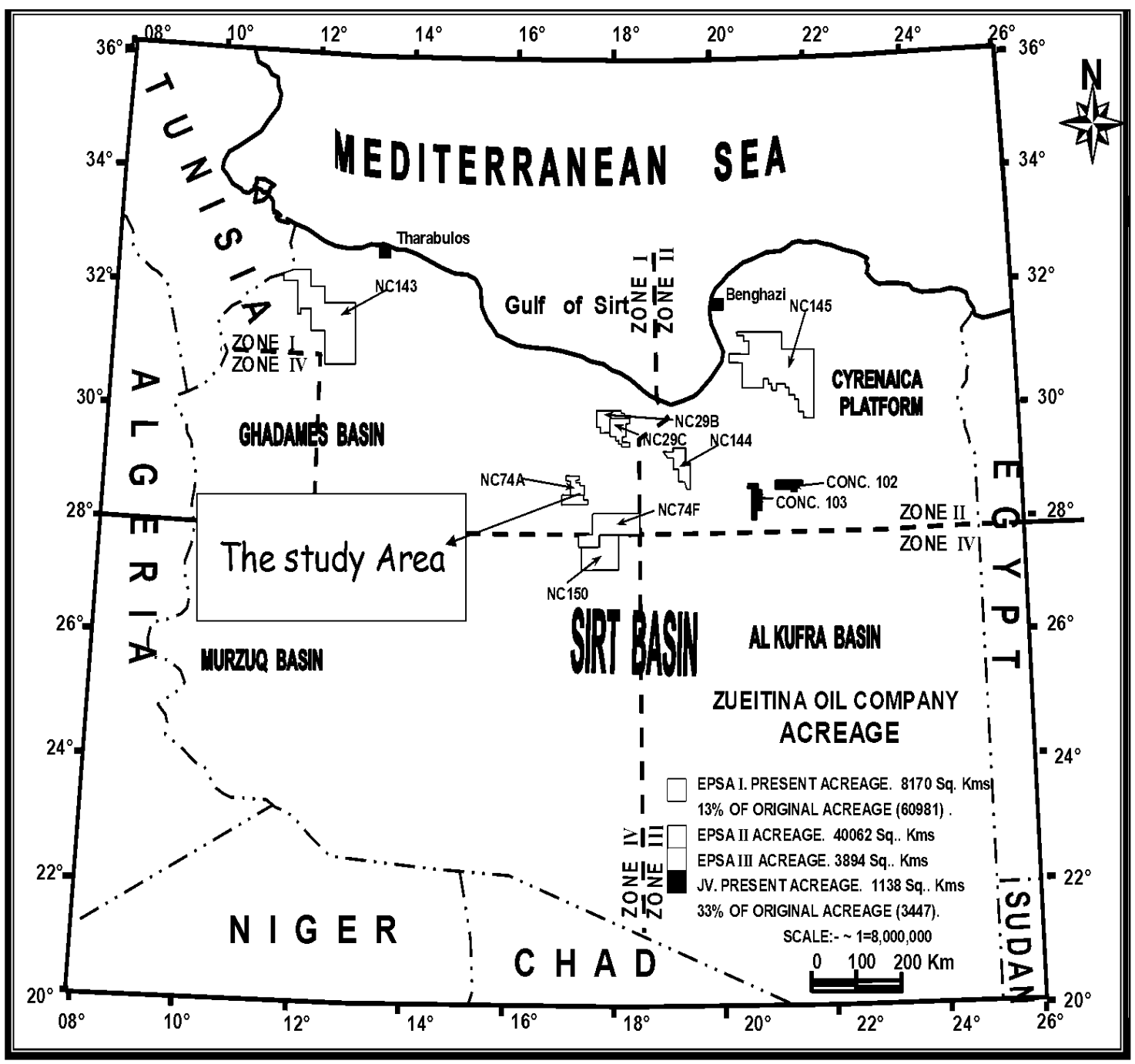

Figure (1): Location Map of the Study Area (After Zueitina Oil Company, 2010).

\section{Geological Setting}

Libya is situated on the Mediterranean foreland of the African Shield, extending over several sedimentary basins. Several tectonic movements and events formed the present major structural and tectonic features, including Caledonian, Hercynian Orogenies of Paleozoic time, and disturbances during Cretaceous to Middle Tertiary times (Conant and Goudarzi, 1967). These events resulted in uplifting, subsidence, tilting, and faulting. Libya was subdivided into major sedimentary basins Figure (2). The first of these basins is Ghadames basin. It is situated in the western part of Libya and it forms the largest geologic depressions in the North African Craton. It is separated from Sirt Basin by Gargaf Arch; it consists of sedimentary rocks deposited at the Paleozoic time. The second one is Sirt basin, which is located in north-central part of Libya and on the onshore of Libya along the Mediterranean coastline. The third is Murzuq basin, which is located in the south-western part of Libya and extends into Algeria and Niger. It is bounded from the East by Tibesti Sirt uplift and from the North by the Gargaf Arch (Conant and Goudarzi, 1967). The last basin is Al Kufrah basin, which is located in the south-eastern part of Libya and extends into Egypt, Sudan and Chad. 
Sirt basin is the newest and most hydrocarbon prolific basin in Libya. Tectonically, this basin is a northwest elongated basin made of a series of northwest-southeast trending platforms (Horsts) and Troughs (Grabens) as shown in Figure (3). The basin has subsided slowly during Cretaceous and Tertiary, and particularly in the Eocene time when the maximum rate of subsidence of the basin was reached (Bellini, E. and Massa, D., 1980). After the opening of Sirt basin, the sea transgressed southward in the subsiding grabens and in the low-standing highs which were subsiding at a slow rate. The sea transgression reached latitude 22 during the late Cretaceous and Paleocene time and consequently, most of the major highs were covered by sea. During the early Eocene, a partial regression of the sea occurred creating restricted conditions over the southwestern part of the basin. New marine transgression occurred in the middle Eocene eliminating those restricted conditions. The marine sedimentation prevailed and continued until the Quaternary, when the basin was covered by continental sediments. Sedimentation in the Basin varies from thick accumulations of organic-rich bituminous shale and deep marine carbonates to shallow marine carbonates and evaporates and returns to shale. The Cycles may have resulted from changes in the sediment supply, from reactivation of faults or from rapid subsidence (Conley, 1971).

Aswad field is located in the Zella Trough, along the southwest margin of Sirt Embayment. It consists of shales, clastic rocks, carbonates, and evaporates accumulated in the downthrown block while up thrown blocks remained above sea level. The basement rocks in the graben areas consist of igneous and metamorphic rocks of Cambro-Ordovician age. Paleozoic rocks had not been penetrated in the high areas of the basin. However, it is thought that they were eroded- off during the Caledonian and/or Hercynian uplifting (Zueitina Oil Company, 2010). Aswad structure is a fault-bounded anticline trending from northwest to southeast direction. Its structure is formed in a graben between two major step faults with downthrown to the east and all over the hanging wall, which creates the structural closure. (Zueitina Oil Company, 2010). 


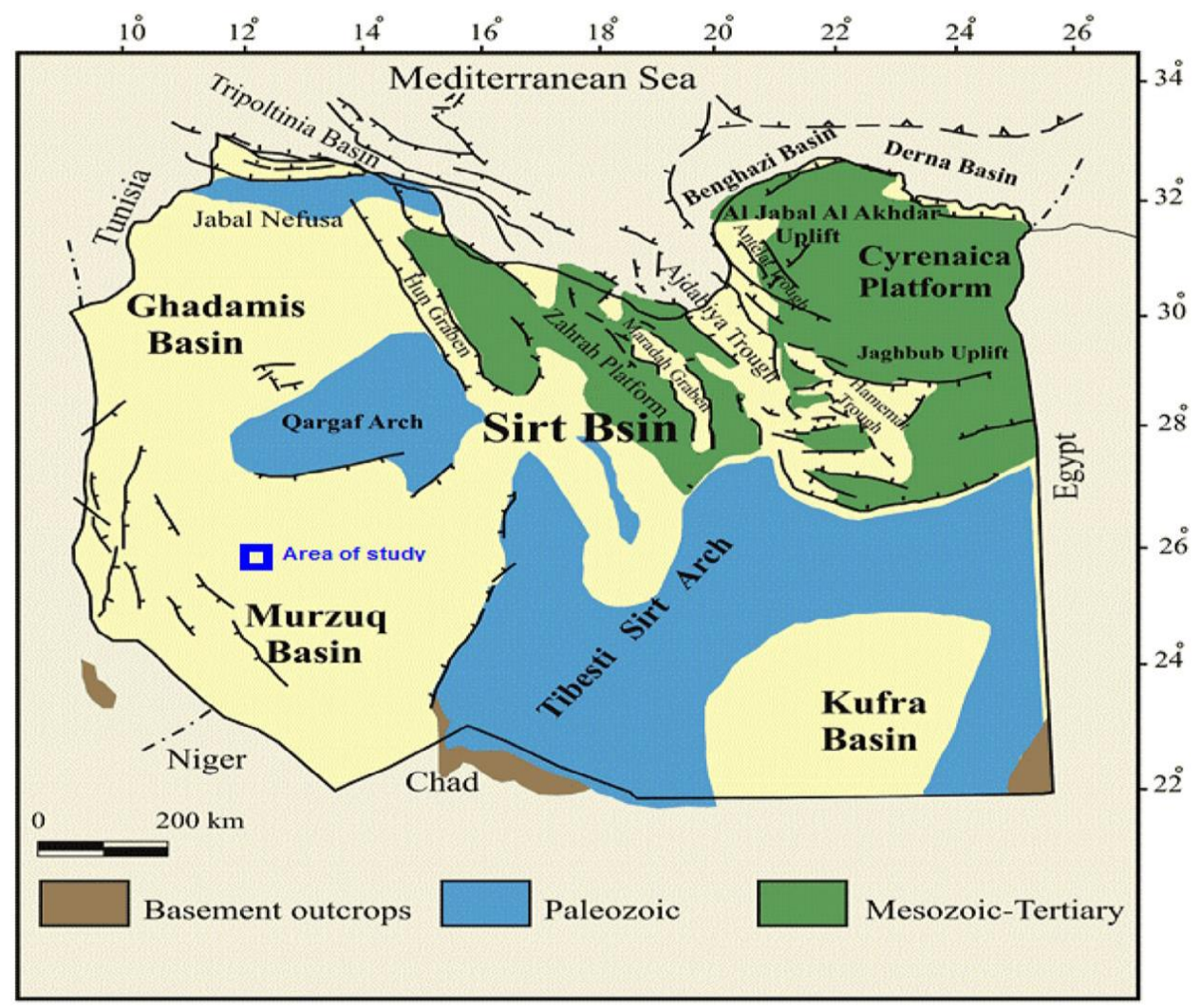

Figure (2): Sedimentary Basins and General Tectonic.

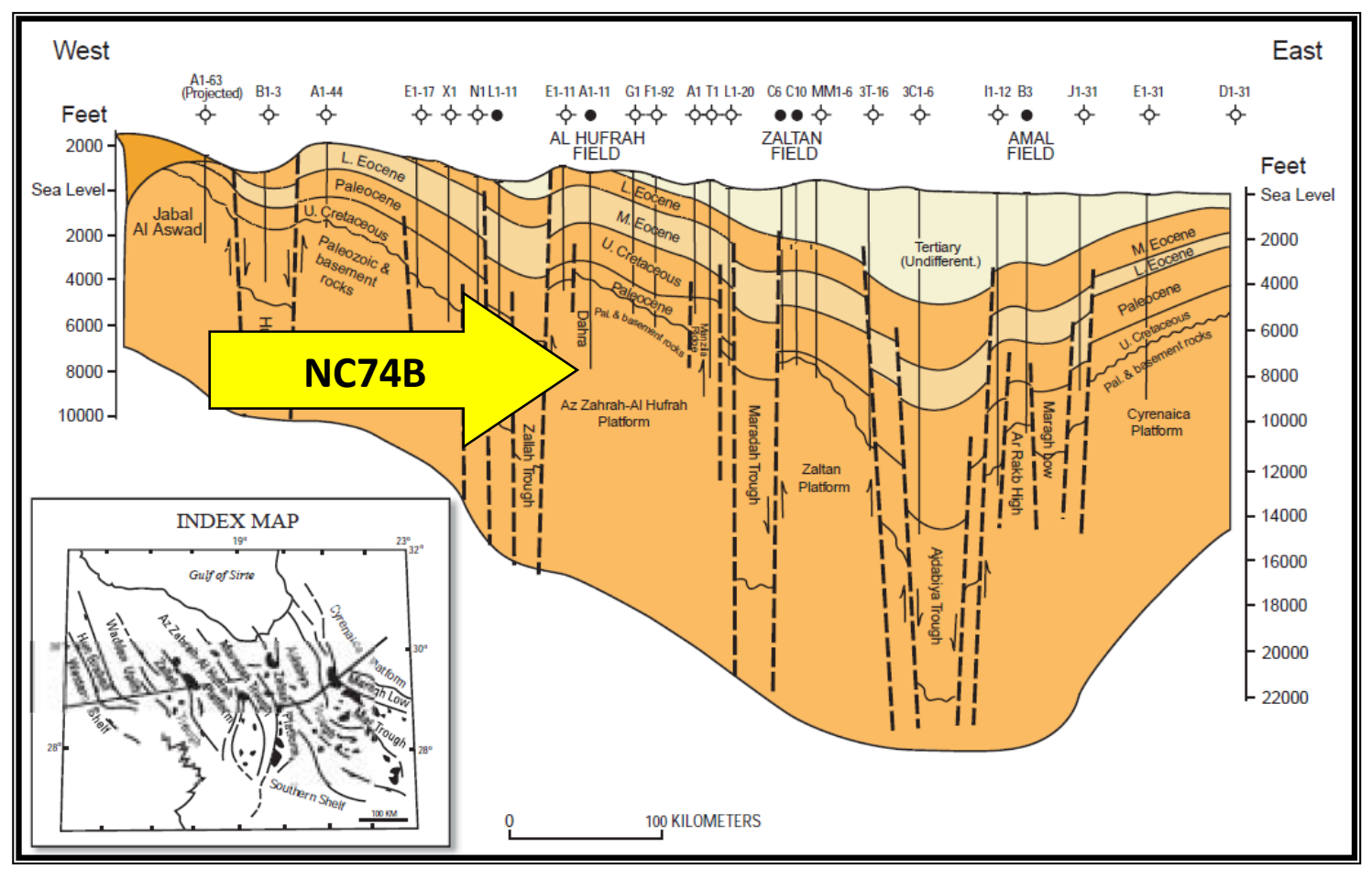

Figure (3): East -West Regional Cross-Section A Cross Sirt Basin (After from Roohi, 1996a). 
Some maps and stratigraphic section have been constructed to show the structure, the different thicknesses of Facha reservoir, and the lithology in the study area. Structure contour map Figure (4) has been carried out for the available wells taking into consideration the geological and structural background of the area. It portrays that the area is structurally controlled and is affected by step faults. This is clearly consistent with the varying thickness of Facha reservoir in the available wells shown in the isopach map Figure (5). The lithology of Facha reservoir consists mainly of dolomites with minor streaks of evaporates and limestone as shown in the stratigraphic section of the wells B13, B5, B14, B6 Figure (6). The Facha dolomite member, as described by (Barr and Weggar 1972), is predominately a tan, argillaceous, finely crystalline, massive, commonly vugular dolomite with minor amounts of anhydrite and limestone beds, occur within the unit, which consist of white to cream and soft argillaceous calcilutite. The Facha Dolomite is conformably overlain by the Hon Evaporate Member occurs at the change from the basal massive anhydrite of the Hon Evaporate Member a dominantly dolomite section. The base of the unit is placed at the change from dolomite or anhydrite to limestone or marl of the underlying formation (Barr and Weggar, 1972).

The Stratigraphic framework of the area of study is very important to understand because it contains most the parameters needed for accumulating hydrocarbon such as reservoir and source, reservoir and cap rocks and their stratigraphic relationships in the area. The stratigraphic column is illustrated in Figure (7). Following the opening of Sirt Basin, a variety of continental and near shore marine sediments was deposited forming the stratigraphic sequences of the basin. It can be divided into four litho-stratigraphic sequences (Barr and Weggar, 1972). The first sequence at the basement is dominated by the Pre-Upper Cretaceous sedimentary cover in the form of Hofra, Gragaf quartzite, and Nubian sandstones, which existed before discovering the basin. The second sequence is the Upper Cretaceous group infill sediments deposited following the structural development of the grabens. These grabens resulted in the accumulation sites of marine shale deposited and eroded from the structural high areas. The stratigraphic sequence deposited includes (in a secondary order) the Bahi, lidam, Etel, Rachmat, Rakab, and Kalash Formation. The third sequence is represented by the Tertiary sediments and is a part of the garden-Fill stage started by the early Paleocene deposits. The Paleocene and early Eocene rock deposits include the Hagfa Beda, Dahra, Zelten and Gir Formation that are widespread and have good lateral Stratigraphic continuity. The fourth sequence starts near the beginning of the Lower Eocene. It is characterized by the slight to moderate local thickness variation within the upper Gir Formation (Barr and Weggar, 1972). The existence or accumulation of oil or gas needs the presence of the following requirements namely the source rocks, reservoir rocks, cap rocks and trapping mechanism (Thomas, 2001). In the study area, Sirt shale Formation (Upper Cretaceous) founds the source rock for the oil accumulation; Hon evaporate of Gir Formation constitutes the cap rocks, and dolomite of Facha member forms the reservoir rock (Zueitina Oil Company, 2010). 


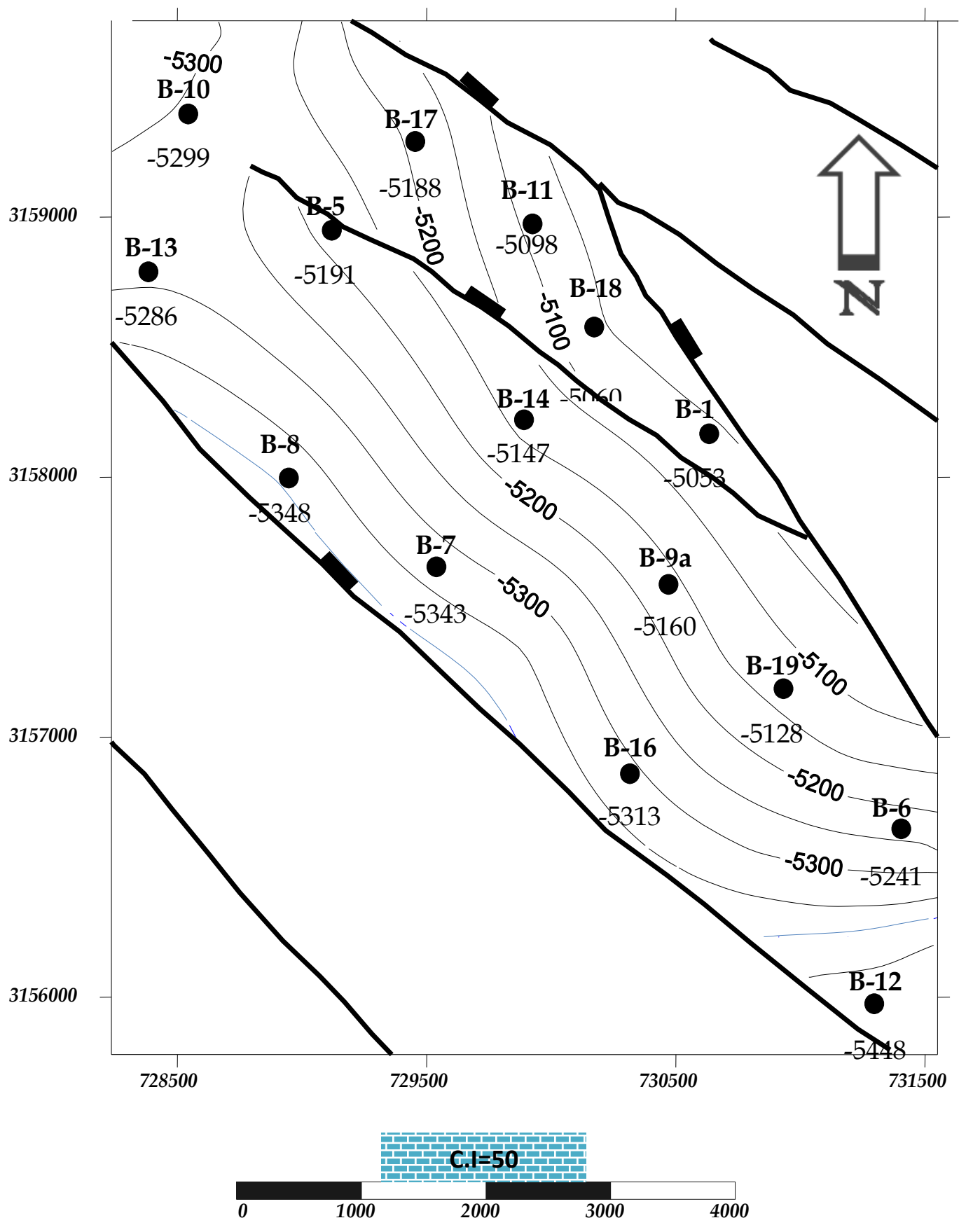

Figure (4): Structure Map of Facha Reservoir in Aswad Oil Field, NC74B, Sirte Basin. 


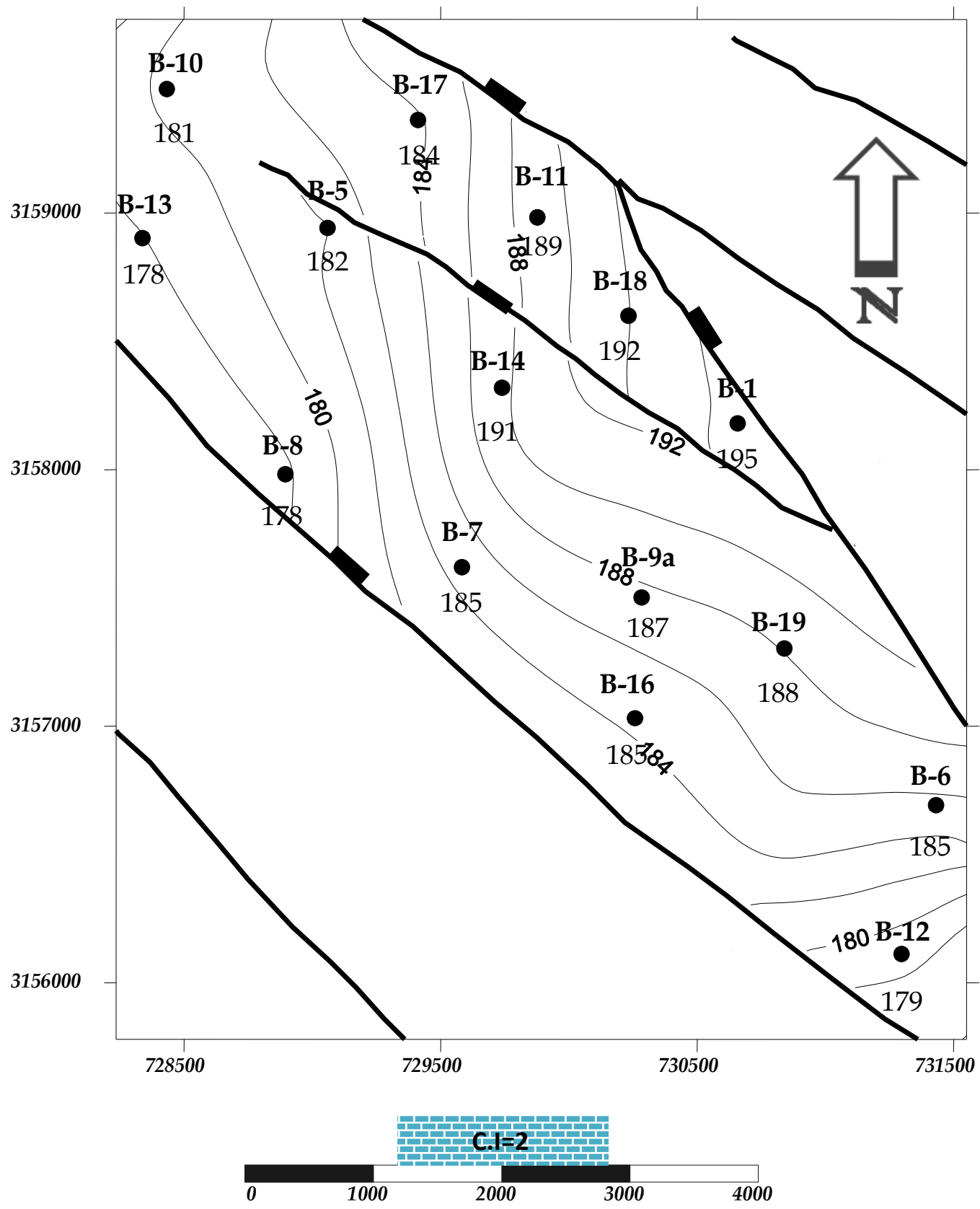

Figure (5): Isopach Map of Facha Reservoir in Aswad Field, NC74B, Sirt Basin. 


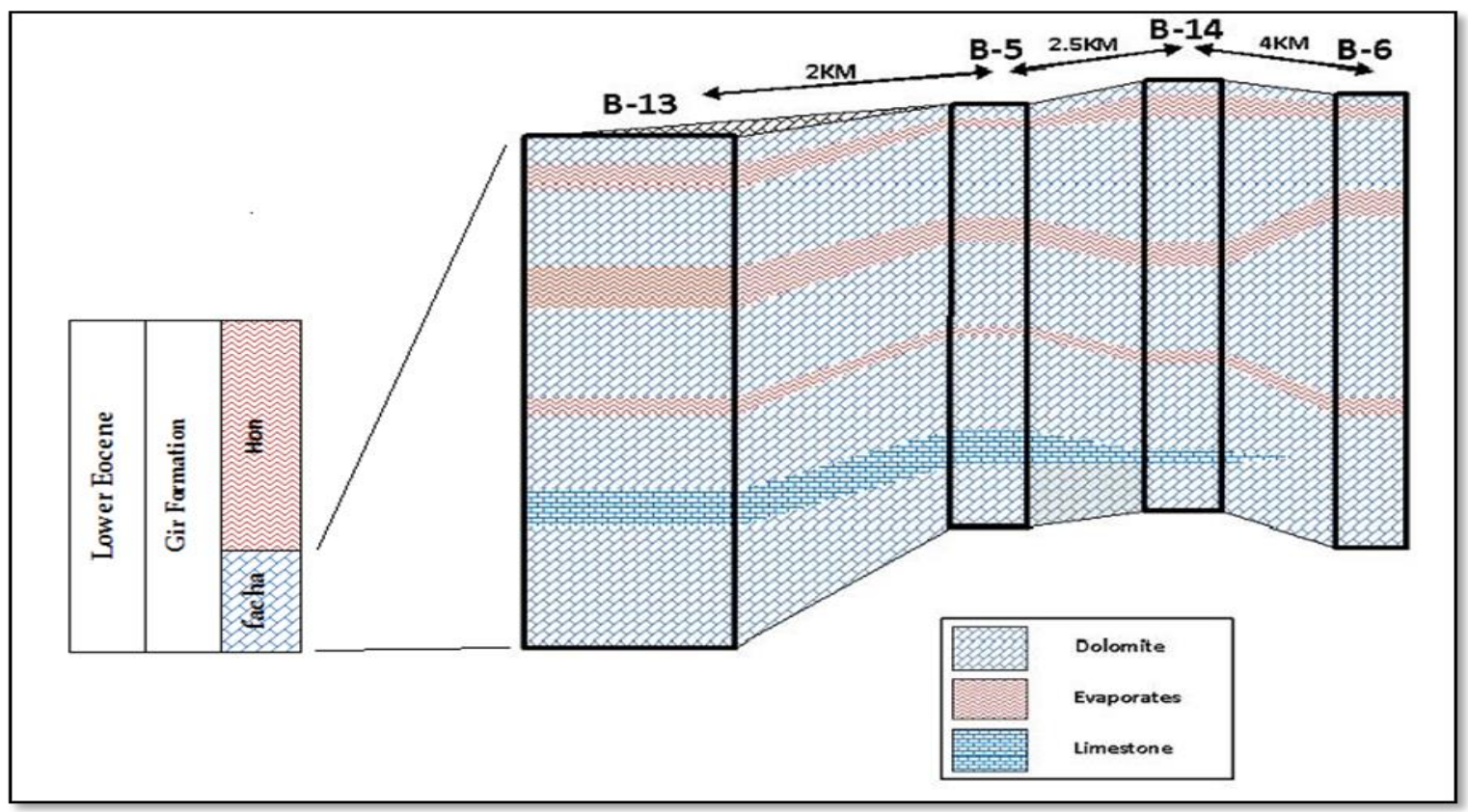

Figure (6): Stratigraphic Section of Facha Reservoir in Aswad Oil Field, NC74B, Sirt Basin.

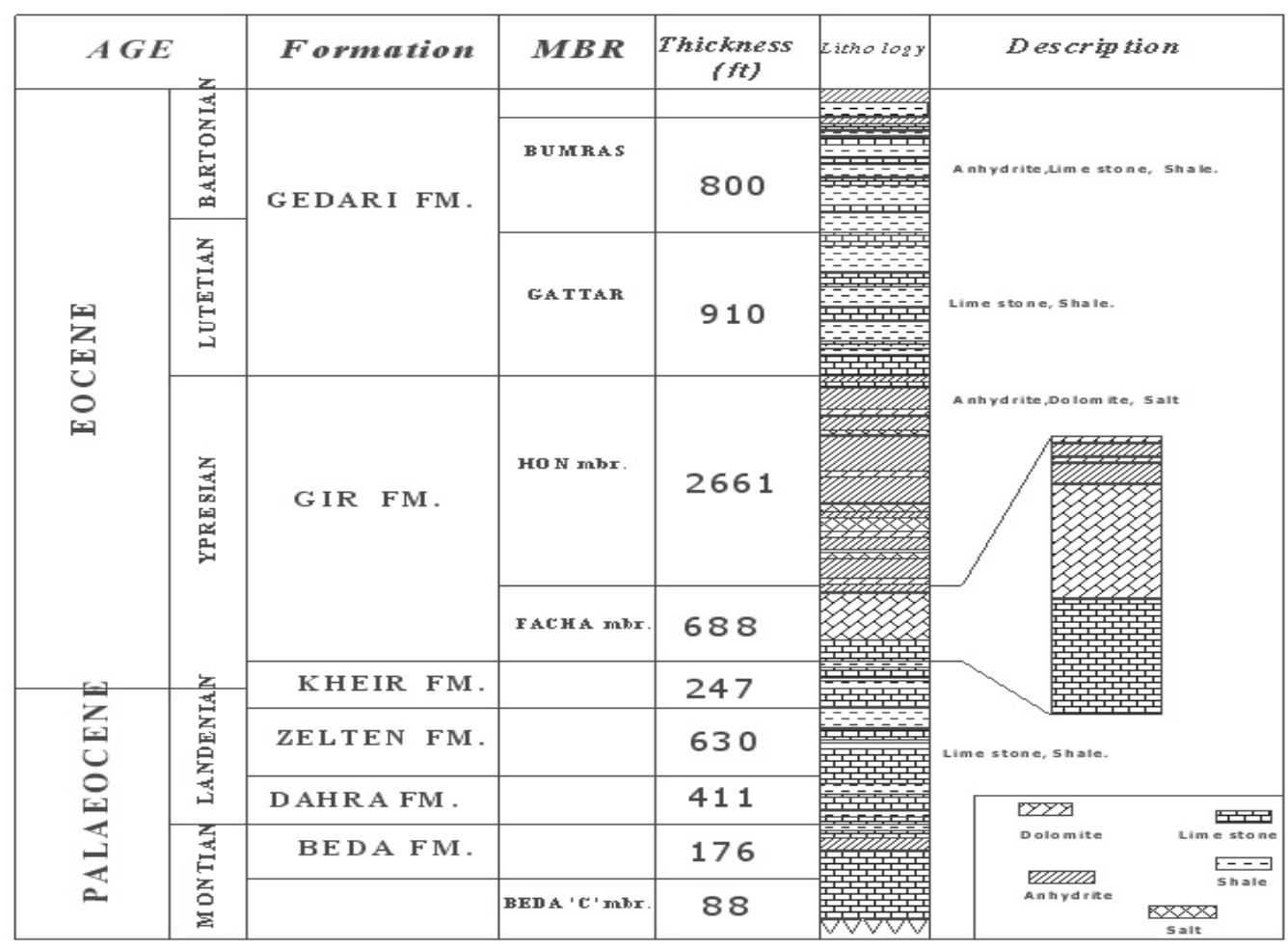

Figure (7): Columnar Section of Aswad Oil Field, NC74B Sirt Basin, Libya. (Modified after Zueitina Oil Company, 2010). 


\section{Methodology and Processing}

The following procedures have been followed in order to analyze and interpret well logging data:

1) The raw log response data have been filtered in order to remove and correct anomalous data points.

2) Neutron, sonic, density and resistivity $\operatorname{logs}$ for mud filtrate invasion have been corrected.

3) Logs of all selected wells have been normalized in order to determine the appropriate ranges of porosity, clay content, water resistivity, etc.

To derive the petro-physical parameters such as water resistivity (Rw) and cementation factor $(\mathrm{m})$, analytical cross-plots have been used. Cementation exponent is an essential parameter in Archie Formula to determine water saturation. This parameter can be obtained from special core analysis. It has been determined through using picket Cross Plot between RT and ØND whereas Shale volume has been determined through using the gamma ray log data. On the other hand, the porosity has been calculated using weighted average neutron density with shale correction (Asquith et al., 2004). The sonic log has been used for determining reliable primary porosity values. The water saturation has been derived using connate water resistivity. The net pay thickens of the Facha reservoir representing-intervals have porosity greater than or equal to the porosity cut-off of $10 \%$, water saturation is less than cut-off of $50 \%$, and volume of shale is less than $30 \%$. These cut-off percentages have been determined from the inspection of the logs and cross plots of the porosity versus Shale. The average of the output results, which was deduced from the well logging parameters, have been calculated and plotted in the form of contour maps.

\section{Output Results of Well Logging Data}

After doing environmental corrections, the preliminary investigation of the well logging data response is of prime importance (Mohamed et al., 2013). To describe many petrophysical characteristics such as the nature of the reservoir in the form of the prevailing lithology, shaliness, porosity, and the possible presence of movable hydrocarbons, the Quick Look Technique of log records is well known and can be used as an alternative to quantitative comprehensive formation evaluation of Hawaz reservoir (Mohamed, 2016). When the reservoir is homogeneous clean with intergranular porosity fully saturated with water, connate water resistivity ( $\mathrm{Rw}$ ) can also be quickly estimated.

The Pickett cross-plot (Pickett, 1972) is one of the simplest and most effective cross-plot methods. In Pickett cross plot, a line of wet resistivity (Ro) at $100 \% \mathrm{Sw}$ is drawn through the most southwest data points; the slope of this line represents the $(\mathrm{m})$ value. The intersection of Ro line with the horizontal axis represents the value $\left(a^{*} \mathrm{Rw}\right)$. Using this method in the researcher it has been found that the average value of Rw is $0.024 \mathrm{Ohm} . \mathrm{m}$, and the average value of $\mathrm{m}$ is 2. A sample for well B8-NC74 Picket cross plot is shown on figure (8). Saturation exponent (n) obtained from special core analysis data equals 2 (Zueitina Oil Company, 2010). The analytical formation evaluation of these wells of Facha 
reservoir reveals lithological facies that consists mainly of dolomite with few limestones as shown in the dia porosity $\rho b / \varnothing n$ cross-plot Figure (9) for well B14- NC74.

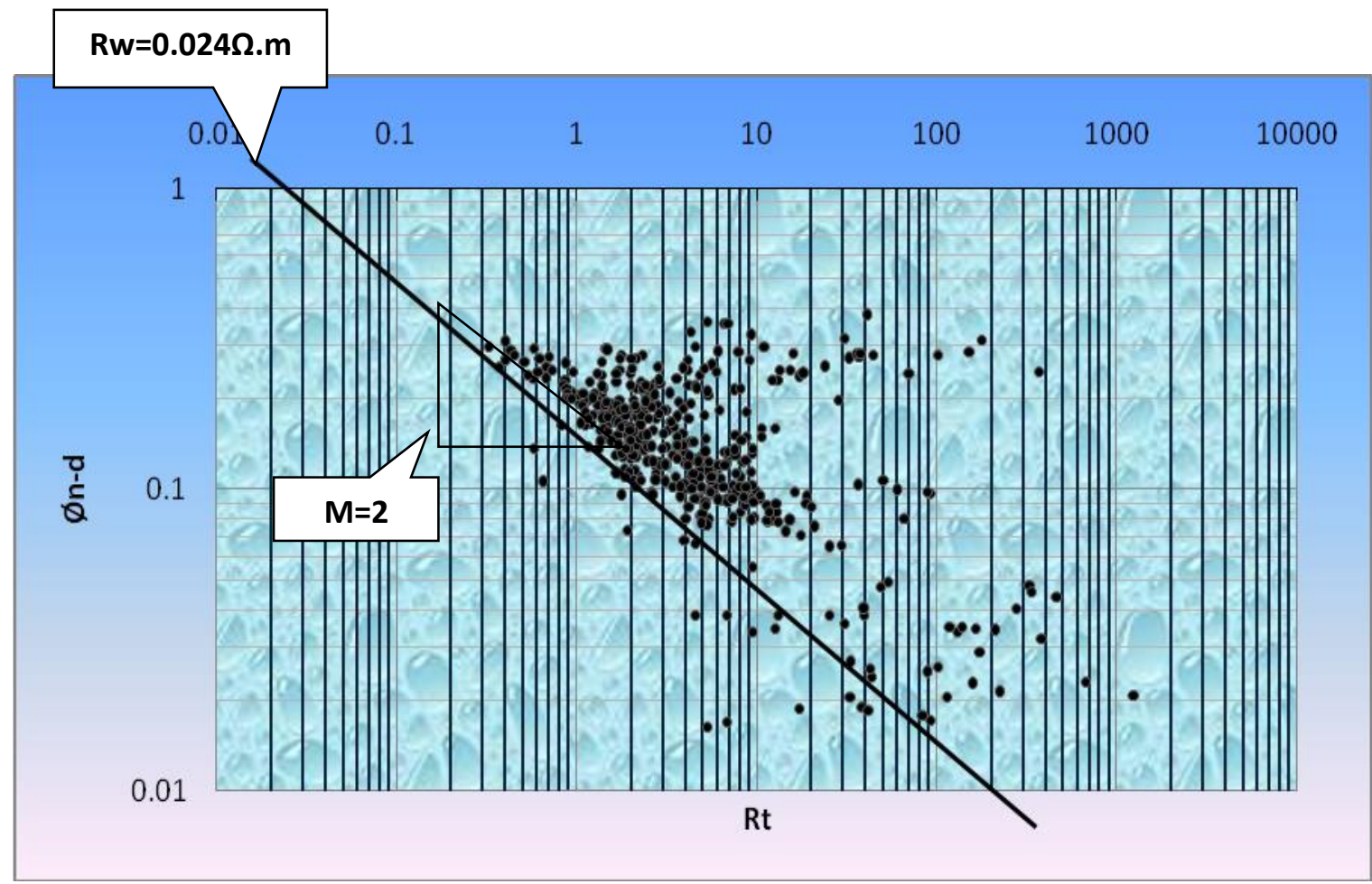

Figure (8): Pickett Cross-Plot that Shows the Relation Between Rt (ohm) and $\emptyset_{\mathrm{N}-\mathrm{D}}(\%)$ of Well B8-NC74.

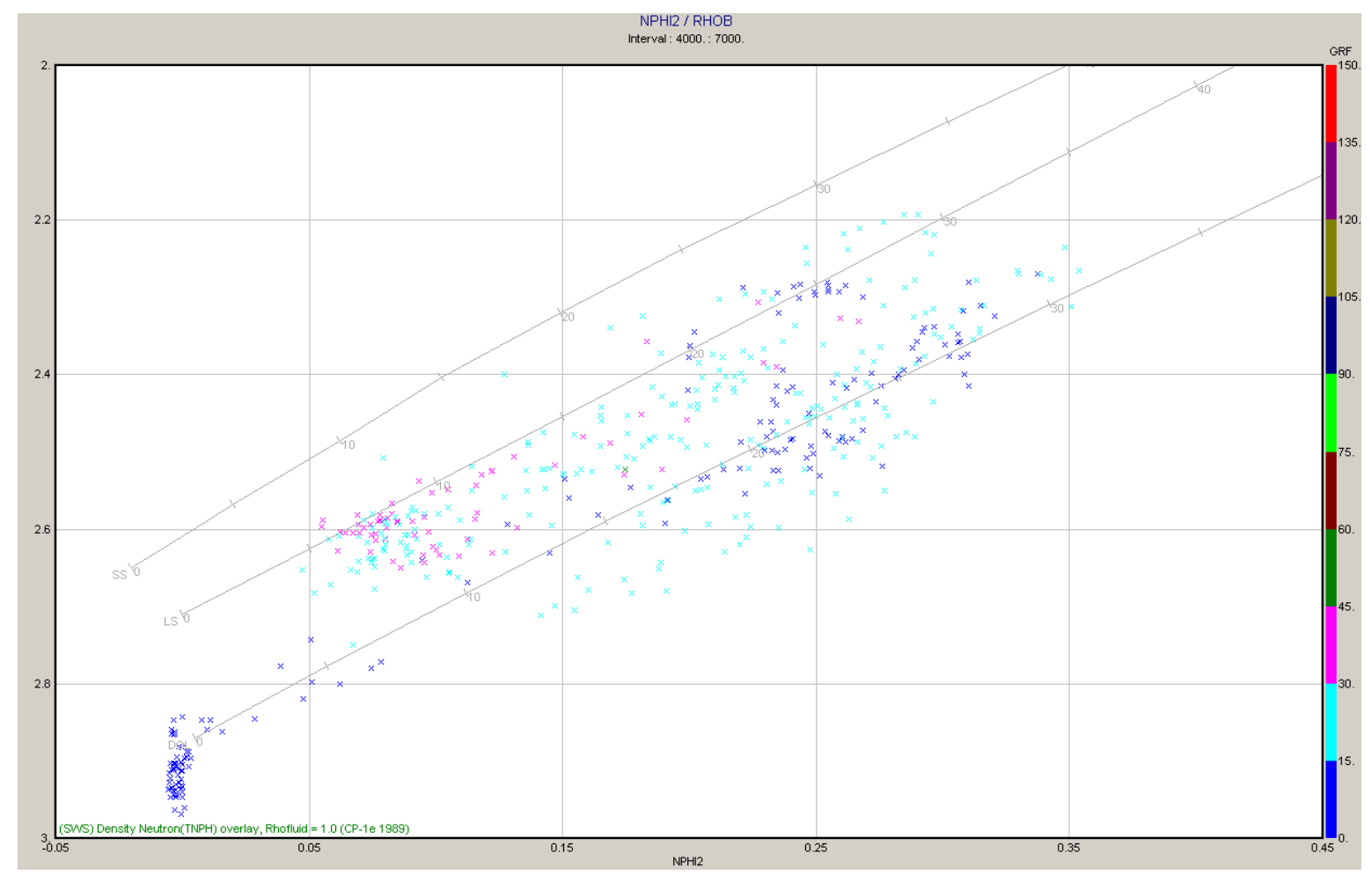

Figure (9): Porosity $\rho b \& Ø n$ Cross-Plot for Hawaz Formation at B14-NC74. 
The well logging deduced from the petro-physical parameters are represented by a number of isoparameteric maps that show the aerial distribution of the Facha reservoir. The net reservoir isopach map on Figure (10) indicates a maximum recorded thickness of $128 \mathrm{ft}$ at well B18-NC74 towards the north east of the study area, while this thickness decreases gradually to the south west reaching $12 \mathrm{ft}$ at well B8-NC74. The contour map of total porosity values of the Facha reservoir on Figure (11) shows a regular pattern of distribution with a general increasing towards the southeastern part of the area with a maximum record value of $23 \%$ at well B8-NC74 but a general decreasing towards the northwestern part with a minimum record value of $10 \%$ at well B10-NC74. The high value of porosity value at well B8-NC74 may be due to the effect of the fault. It can be noticed that the high porosity values in NW area correspond to the low value of shale. The water saturation contour map of the reservoir on Figure (12) shows a general increase towards the south with a maximum value of $93 \%$ at well B16-NC74. On the other hand, this contour map shows some kind of a gradual decrease towards the eastern and southeastern sides of a minimum value of 52\% at wells B6 and B18-NC74. From the above-mentioned results, it can be concluded that Facha member has a good petro-physical parameters because of the low shale volume and the relatively high porosity. The oil water contact (OWC) in the reservoir can be determined by plotting water saturation values versus subsea depths. Fig.13 for well B8-NC74 indicates that the oil water contact of the Facha is at a subsea depth of $5390 \mathrm{ft}$.

\section{Summary and Conclusion}

After investigating the petro-physical characteristics of the Facha Reservoir, it can be concluded that this field is structurally controlled since it is located in the Zella Trough, along the southwest margin of the Sirt Embayment. It consists of shales, clastics, carbonates, and evaporates that accumulated in the downthrown block while the up thrown blocks remained above sea level. Generally, Aswad structure is a fault bounded anticline that trends from northwest to southeast directions. The structure contour map of Facha reservoir indicates that the area is structurally controlled and is affected by step faults. This is clearly consistent with the varying thickness in the available wells, shown in the isopach map of Facha reservoir, because of the deposition over an irregularly eroded surface and the differential erosion at the top. The analytical formation evaluation of Facha reservoir reveals lithological facies that consist mainly of dolomite and little limestone. The petrophysical parameters indicate that Facha member is a good reservoir because of the low shale volume and the relatively high porosity. The oil water contact of the reservoir has been be determined by plotting the calculated water saturation values versus subsea depths. (This sentence cannot be within the conclusion it is related to methodology OR analysis. Recheck with the researcher). 


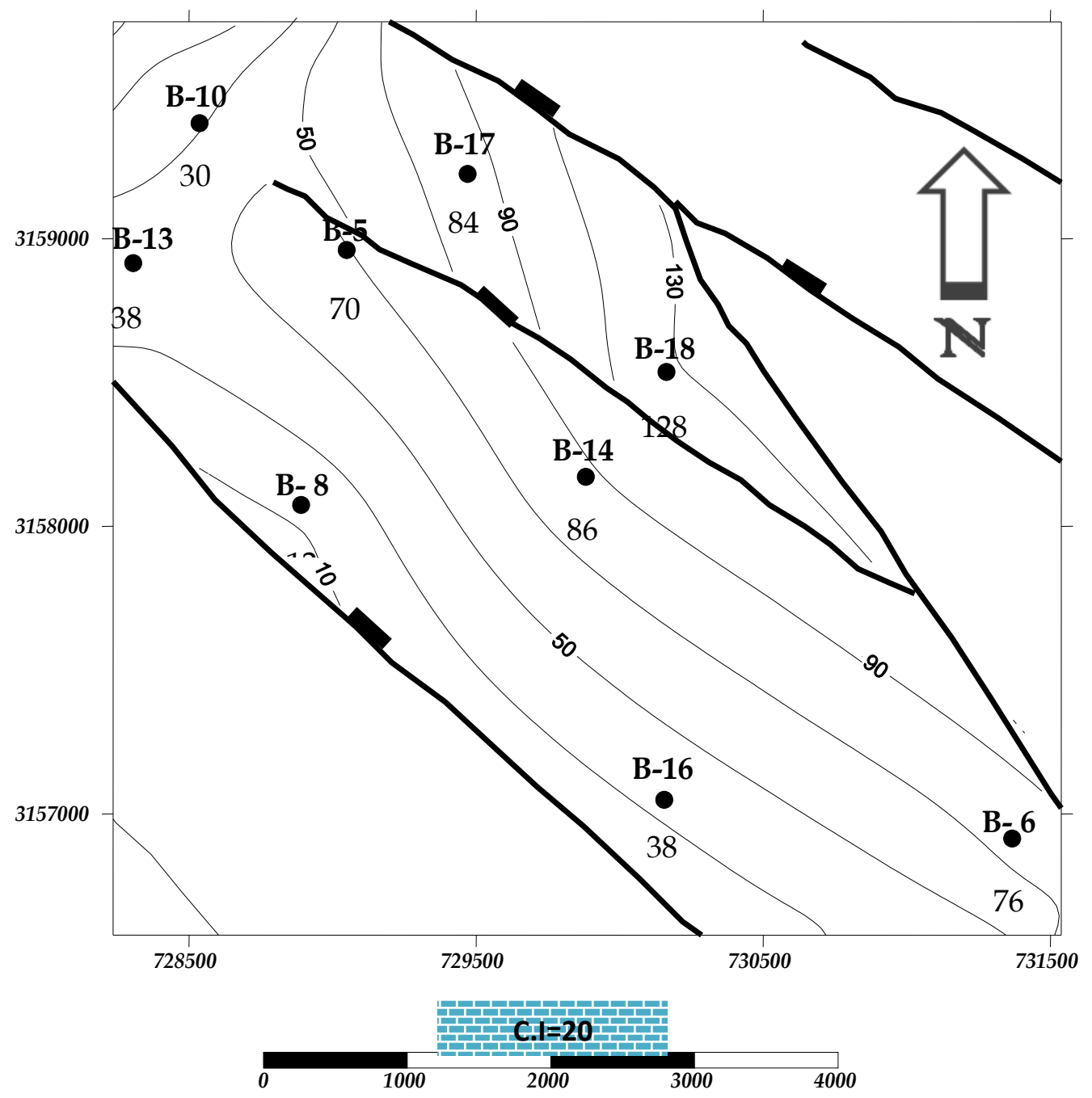

Figure (10): Shows the Net Pay Thickness Map Distribution in The Facha Reservoir A Cross the Aswad Oil Field Block NC74B- Sirt Basin. 


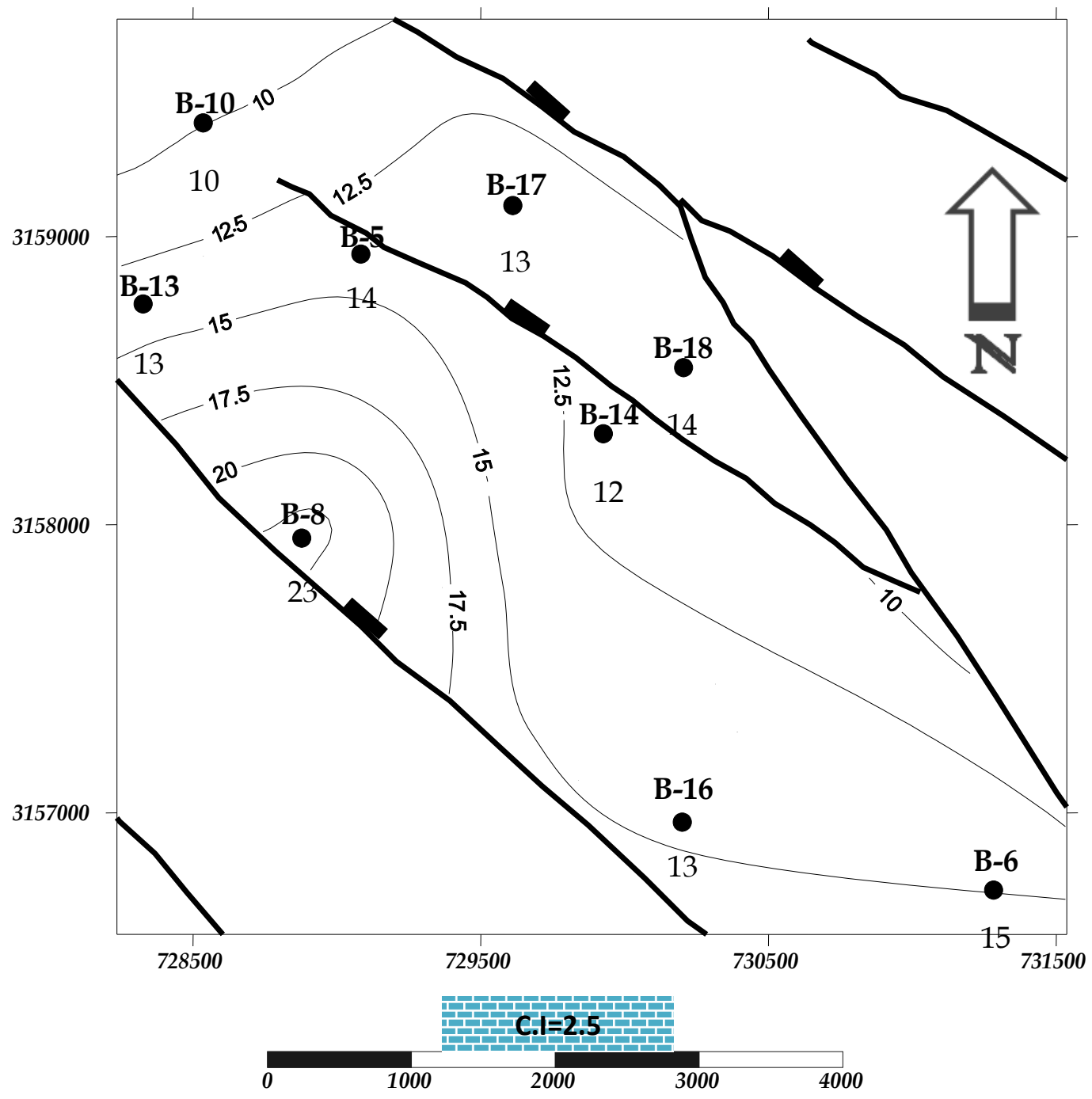

Figure (11): Shows the Average Porosity Map Distribution of The Facha Reservoir A Cross the Aswad Oil Field Block NC74B- Sirt Basin. 


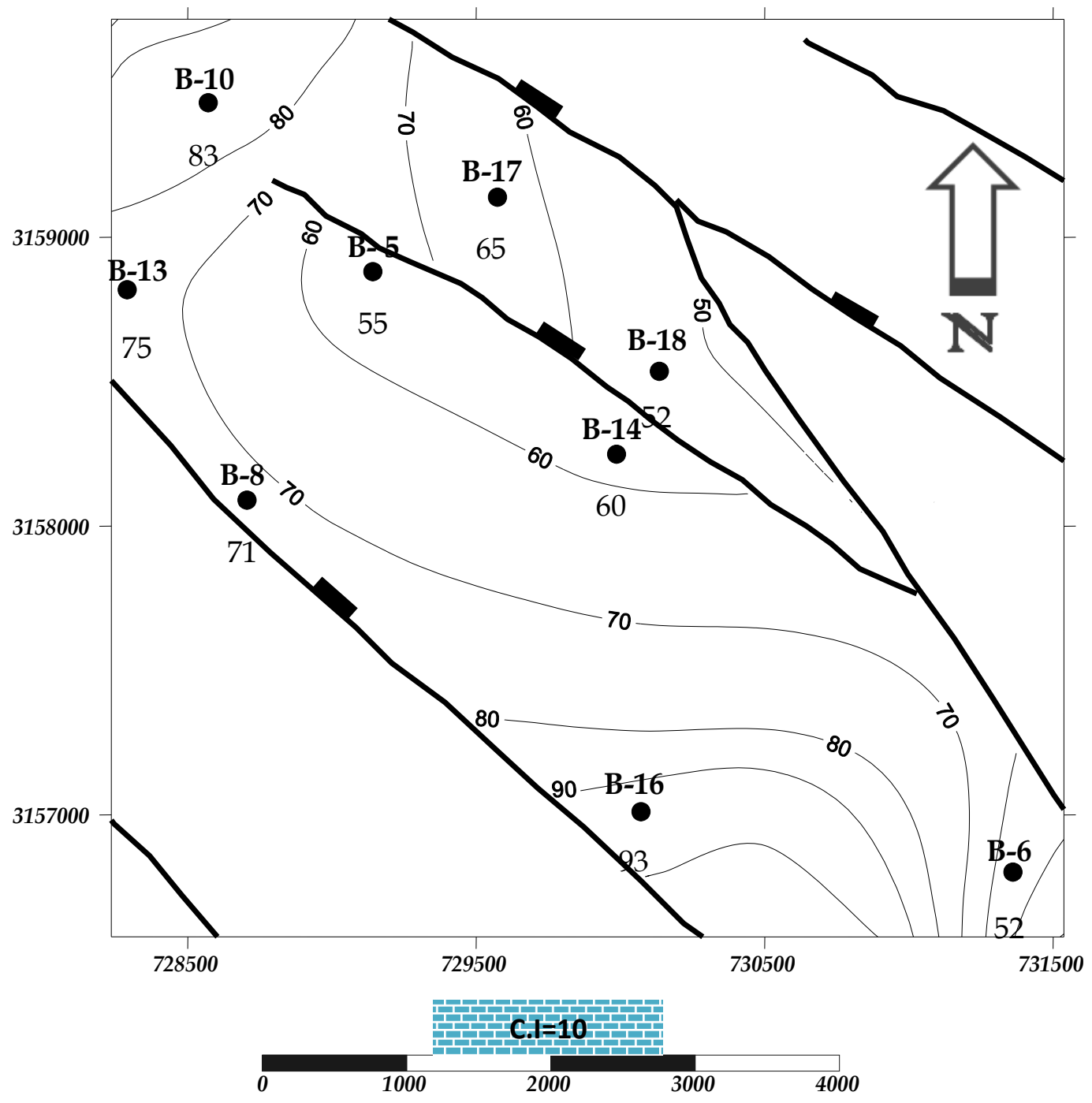

Figure (12): Shows the Water Saturation (Sw) Map Distribution in The Facha Reservoir A Cross the Aswad Oil Field NC74B - Sirt Basin. 


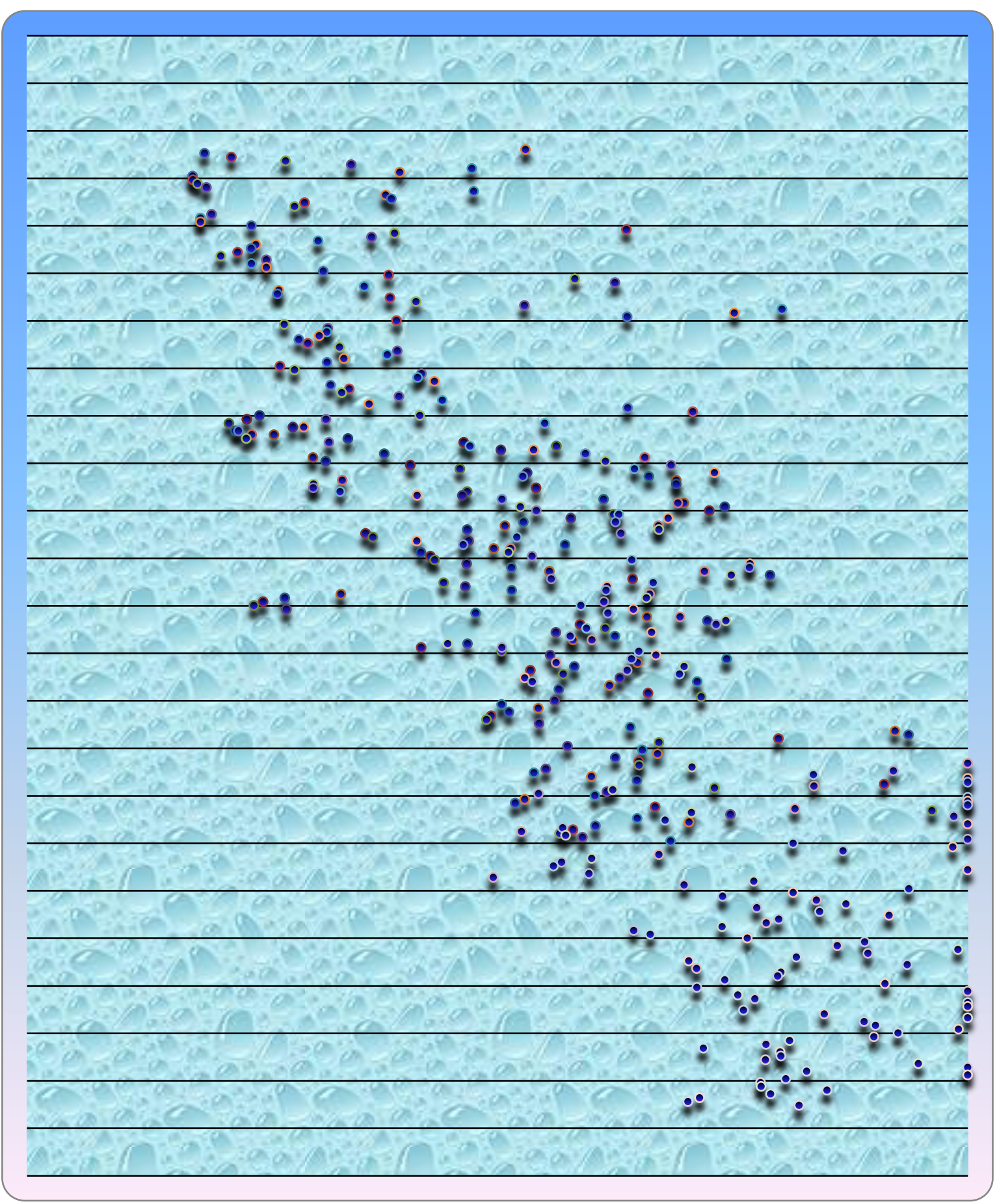

Figure (13): Water Saturation Versus Depth Plot in Well B8-NC74 of Aswed Oil Field, Sirt Basin.

\section{Acknowledgment}

We would like to thank Zueitina Oil Company for providing us the well logging data and the materials for preparing this paper. 


\section{References}

- Asquith,G. and Gibson, C., (2004). Basic well log analysis for geologists, the American association of petroleum geologist, Tulsa, Oklahoma 74101 USA.

- Barr F.T. and Weggar A.A. (1972), Stratigraphic Nomeneclature of Sirte basin, Libya Petroleum Exploration Society of Libya.

- Bellini, E. and Massa, D., (1980). A stratigraphic contribution to the Palaeozoic of southern basins of Libya. In: Salem M. J. and Busrewil M. T (Eds.). The Geology of Libya. Academic press, London, Vol. I, P. 3 - 56.

- Conley C.D. (1971), Stratigraphy and Lithofaies of Lower Paleocene, Sirte basin, Libya. In. Symp Geol. Libya, (ed.C. Gray). Fac.Sci, Univ. Libya, Tripoli.

- Conant C, L. ouis and Goudarzi, G.H, (1967) Stratigraphic and tectonic Frame work of Libya.

- Mohamed, A., Ibrahim, E., Sabry, A., (2013). Petrophysical characteristics of Wakar formation, Port Fouad marine field, north Nile Delta, Egypt. Arabian J. Geosci. 6, 14851497.

- Mohamed, K., (2016). Reservoir quality of Hawaz Formation, J oil field, Concession NC186, NW Murzuq basin, SW Libya. Arabian J. Geosci. 9 (2), 1-17.

- Pickett. G.R. (1972), practical formation evaluation Golden Colorado.

- Selim EI, Kamel A, Kashlaf A (2015). Hydrocarbon probability of middle Ordovician Hawaz formation, Murzuq basin, southwestern Libya. Arab J Geosci; 8:5531-60.

- Selly, R. C, (1968), Facies profiles and other methods of graphic data presentation; Application in quantitive study of Libyan Tertiary shoreline deposits: Sed. Petrology, v.38, p.363-372 .

- Thomas S. Ahlbrandt (2001), The Sirte Basin Province of Libya, Sirte Zelten, Total Petroleum System.

- Zueitina Oil Operations (2010), Geological review of Aswad, (Zueitina Oil Company, logs and unpublished reports. 